\title{
CINA BENTENG: \\ THE LATEST GENERATIONS AND ACCULTURATION
}

\author{
Billy Nathan Setiawan \\ Intercultural Communication, School of Arts, Languages, and Cultures, University of Manchester \\ Oxford Road, M13 9PL, Manchester, United Kingdom \\ billy.setiawan@postgrad.manchester.ac.uk
}

\begin{abstract}
The aim of this paper was to investigate the acculturation process encountered by the two latest generations of Cina Benteng. A Skype interview was conducted with two young Cina Benteng descents. The analysis was also supported by insightful remark from the parents of the two interviewees. This study discovers that the two generations seem to respond to the acculturation process in different ways. However, although some traditions are no longer relevant to the later generation, their identity as a Chinese descent cannot be easily removed.
\end{abstract}

Keywords: Cina Benteng, Chinese Indonesians, acculturation

\begin{abstract}
ABSTRAK
Artikel menelaah sejauh mana dua generasi terakhir dari etnis Cina Benteng mengalami proses akulturasi. Data diperoleh dari wawancara melalui Skype dengan dua orang muda keturunan Cina Benteng. Analisis diperkuat dengan opini dari orangtua kedua responden. Studi menunjukkan bahwa kedua generasi memperlihatkan respons yang berbeda terhadap proses akulturasi. Walaupun beberapa tradisi tidak lagi relevan di kalangan generasi terakhir, identitas mereka sebagai etnis keturunan Tiongkok tidak bisa dihilangkan begitu saja.
\end{abstract}

Kata kunci: Cina Benteng, keturunan Tiongkok, akulturasi 


\section{INTRODUCTION}

The acculturation process varies through different generations. Earlier migrants might have fond and deep nostalgia of their origins. Over time, the nostalgia might be fading. The descendants, those who are born in the new place, might find itirrelevant to talk about the collective memory of their past origin. Some are remembered; some are let forgotten.

This paper intends to investigate to what extent thetwo latest generations of Cina Benteng (translated: 'Chinese of the Fort', one of the Chinese Indonesian ethnic groups) encounter acculturation process. Some research has been conducted to examine the early generations of Cina Benteng, yet there has not been much study revealing the latest generations. The data were collected from a Skype interview with two young Cina Benteng descents born and brought up in Tangerang, the main base of Cina Benteng community.

The history of ethnic Cina Benteng and a brief portrayal of the earlier generations will be provided, followed by the description of the informants' experience and their parents' life story. The experience and the life story will be linked to Berry (1990). Boski (2008) will then sharpen the analysis. In addition, the discussion in this paper will be supported by personal insight and points of view as a Cina Benteng descent. Thus, the writer realises that the analysis might not represent the whole idea of Cina Benteng ethnic group.

In the end, a brief summary and some in-depth questions of the future of ethnic Cina Benteng will conclude the study.

\section{Theories in psychology of acculturation}

The way individuals deal with acculturation might differ than how the groups do in a bigger scale. There are two levels of this process that make a division between collective and individual acculturation (Berry, 1990). The population level, which includes ecological, cultural, institutional and social factors, might stimulate a transformation in social, economic and political structure. The individual level, on the other hand, reflects changes in one's behaviour, values, identity and attitudes. These changes might be influenced by interaction with another culture or individuals' participation in collective transition. The changes that the individuals experience are then described as psychological acculturation.

Berry (1990) also noted that acculturation process includes several key elements. The contact or interaction between two cultures results in changes both in aspects of culture and psychology of the people involved. These changes tend to be passed down to the next generation. Furthermore, dynamic activities are involved before and after the contact. Individuals characterise certain aspects of life such as their preferred education, media, religion, education, politics, daily practices and social interactions. It then defines a relatively stable way of living in the acculturative place.

Furthermore, Berry (1990) defined four varieties of acculturation based on the orientation to maintain cultural identity and characteristics and the importance of sustaining relationship with other groups. According to
(Berry, 1990), assimilation occurs when the acculturating group or person does not wish to uphold his/her identity. In contrast, when the original culture is cultivated and interaction with other groups is avoided, the idea of separation is defined. When maintaining original culture and interacting with other groups are seen as important, integration takes place. Last, when there is not much interest in maintaining original culture and interaction with other groups, marginalization occurs.

Responding to Berry's, Boski (2008) argued that integration is the most desirable option among the acculturating individuals. He defined five levels of integration. In level 1 (acculturation attitudes), individuals feel comfortable living in two cultural worlds. S/he acquires the needs of being fluent in the languages of both cultures and contact with both groups. Level 2 (perception and evaluation) defines a merging point of the two cultures, in which 'similarity'or 'third value' is viewed. In level 3 (functional specialisation), individuals (usually a family) are able to develop separation at home, while in public domains they manage to apply assimilation. When the individuals are able to become a bicultural person, level 4 is defined. Finally in level 5, noted down from Bennett (1993) and Bennett and Bennett (2004), integration is equalized with marginalisation, where individuals find themselves in a pluralistic world and do not belong to any cultures. This could relate to the idea of cosmopolitanism, in which everyone is a citizen of the world

\section{Ethnic Chinese in Indonesia from time to time}

Ethnic Chinese has existed in Indonesia for a very long time. During the Dutch colonialism, as noted in Coppel (1999; 2001), ethnic Chinese was classified as "foreign oriental". Overtime, there has been a strong distinction between Chinese Indonesians and indigenous or local Indonesians. Budiman (2005) noted that during the Soekarno (first president of Republic of Indonesia, 1945-1965) era, ethnic Chinese in Indonesiawere viewed in two different positions. On the one hand, Consultative Body for Indonesian Citizenship proposed that Chinese must be allowed to maintain their culture and seen as a part of Indonesia's rich ethnic diversity. This (also known as the left) was led by Soekarno and supported by the Communist Party. On the other hand, Institute for Development of National Unity seemed to lean more to assimilation, emphasising that ethnic Chinese had to give up their culture and fully adjust to Indonesian culture, values and tradition. This was shared by the Indonesian military and Muslim groups.

After the 1965 conflict against the Communist Party led by the Indonesian military,the new regime (known as the New Order) led by Soeharto was forcing ethnic Chinese in Indonesia to completely assimilate. The term 'Cina', which referred to Chinese Indonesians and sounded more insulting, became official to replace 'Tiongkok' or 'Tionghoa'. Chinese Indonesians were obliged to have an Indonesian name (ibid).

Chinese culture, including the use of Chinese characters in public and Chinese festivals, was banned. The separation between 'Cina' and 'pribumi' (common term for local Indonesians) was obvious. Many Chinese Indonesians have been known wealthier and more 
successful than locals. A lot of them own a business. It has created a big social gap. Things had not really changed until 1998. When Indonesia was facing a monetary crisis in 1998, a bigger conflict between 'Cina' and 'pribumi' burst in some big cities. Shops and houses owned by Chinese Indonesians were robbed and burnt. A great number of Chinese Indonesians (believed to be over a thousand) were killed; the womenwere raped. Chinese Indonesians were forced to hide their identity.

The clash brought both positive and negative impacts. Indonesians' fourth president, the late $\mathrm{KH}$ Abdurrahman Wahid (well-known as Gus Dur) dismissed the law that discriminated Chinese Indonesians. In 2002, the next president, Megawati Sukarnoputri,declared Chinese New Year as a national holiday. Chinese cultural symbols and traditions, such as 'liong' and 'barongsai' (dragon and lion dance) were showed in many public events. However, although Chinese Indonesians are becoming more accepted nowadays, many of them are still attempting to find what so-called 'a place' in Indonesian society.

\section{History of Cina Benteng}

Ethnic Chinese are spread out in some cities in Indonesia. The latest population census in 2010 notes that there are approximately 2.8 million Chinese Indonesians (Franciska, 2014). The most well-known ones are Cina Medan (based in Medan, North Sumatera), Cina Bangka (in Bangka), Cina Jawa (in Semarang and Surabaya) and Cina Singkawang (West Kalimantan). There are also some smaller Chinese groups such as Cina Benteng, based in Tangerang (a greater area of Jakarta), Banten province.

Unlike other Chinese Indonesian ethnic groups, which are usually associated with great wealth and fortune, Cina Benteng tend to be looked down in terms of their social status. News on TV or newspaper articles often discus their low economic status and underprivilegedliving condition. Their skin is not as light as other Chinese Indonesians. It is rather darker as 'pribumi' are. Yet, their eyes are slanted, a typical characteristic of Chinese.

Arif (2014) noted that it has been the sixth or seventh generation of Cina Benteng since they first arrived in Indonesia. Due to the Dutch massacre of Chinese population in Batavia (now called Jakarta) in 1740, Chinese people escaped to Tangerang and Bekasi. They started to live in some outskirt areas of Tangerang such as Kedaung, Kampung Melayu, and Teluk Naga (Arif, 2014). The word benteng (translated: fort) refers to the fortress along the Cisadane River, Tangerang, built by the Dutch during colonialism. The Chinese who moved from Jakarta then lived in the area that used to be the fortress. From this occasion, the term Cina Benteng (Chinese of the Fort) was created. The Chinese then started to assimilate with the local culture. They married to the local women. Some of them even converted to Moslem and refused to eat pork (Sugianta et al., 2012; Arif, 2014).

In the 1900s, Cina Benteng gave significant contribution to the Dutch colonialism in Tangerang. It then created anger from the pribumi and an ethnic clash between the pribumi and Cina Benteng occurred in 1946 (Arif, 2014). The houses of Cina Benteng people were looted. Those who survived there or came back later no longer owned property. Some of them lived in a brick or bamboo house along the Cisadane River. It then defined their social status, the main thing that distinguishes them from the other ethnic Chinese in Indonesia.

Ethnic Cina Benteng has displayed two different characteristics of their own. On the one hand, they still hold their 'circle of life' tradition such as the wedding and funeral. They still celebrate the big days of Chinese (Imlek - Chinese New Year, Cap Go Meh - the 15th day of the new year and Peh Cun - boat race festival). They also have a special part in their house dedicated to their ancestors (ibid). On the other hand, ethnic Cina Benteng has successfully assimilated with the pribumi, especially ethnic Sunda (West Java) and Betawi (Jakarta). It can be seen from the modification of their traditions. In their traditional wedding, the groom wear typical Chinese clothes while the bride wear clothes from ethnic Betawi. The music played at the wedding, called gambang kromong, is derived from coastal Sundanese music. Many Cina Benteng people do not speak Chinese. They have their own dialect or vocabulary; some of them are combination of rough Chinese, Indonesian and Sundanese or Betawi (Nurafni, 2012).

Elder generations of Cina Benteng may have firm knowledge of their traditions. Over time, the young generations encounter a different way of acculturation. The data taken from the interviews in this study will investigate how individuals from two generations of Cina Benteng adjust their lives to local settings in Indonesia. The variables mentioned in Berry's (1990) study such as education, media, political participation, religion, language, daily and social practices will be the foundation of the analysis.

\section{METHODS}

In order to get a better sense of the acculturation process of the current generations of CinaBenteng, qualitative research was conducted in this study. Lodico, Spaulding, and Voegtle (2006:264) explained that qualitative research is "the study of social phenomena and on giving voice to the feelings and perceptions of the participants under study". Qualitative research is best used in this study to gain information of how the latest generations of Cina Benteng have encountered a different notion of acculturation. Furthermore, the phenomenology (Qualitative Research, n.d.) is used as an approach to gather sufficient data. This study aims to gain access to the life-world and experiences of the latest generations of Cina Benteng.

I did a Skype interview with two young Cina Benteng descents (a 19 year old female and 22 year old male). I have direct contact with these two informants. The interview was done in both English and Indonesian language. I then requested them to interview their parents and record the conversation (in Indonesian language). Due to the distance and time difference between I, as the researcher, and the informants, a Skype interviewed was conducted instead of face-to-face interview. One of the families lives in the area of Cina Benteng community in the city of Tangerang, while the other one lives outside the Cina Benteng community. Questions in the interview 
are based on Berry's (1990) theory of psychological acculturation and five meanings of integration proposed by Boski (2008).Questions include the participants' activities and hobbies, what they know about Cina Benteng and their ancestors, what they remember from their childhood, kind of school they have attended, language spoken at home and some daily practices such as food served at home. Although the respondents did not mind their real names to be published, for the matter of confidentiality the respondents were renamed.

\section{RESULTS AND DISCUSSION}

\section{Another dimension of acculturation attitude and the third value}

The first informant is Tanti, a 19 year-old girl studying Accounting. She is among other fortunate Cina Benteng descents in her generation, whose family is able to send them to one of the popular universities in Jakarta. Earlier generations, looking at my own family, tend to underestimate education. After high school, they mostly worked in the family business, or if less unfortunate, worked in the marketing (as a sales person). In the past, from my personal view and observation as a Cina Benteng descent, starting a new family seemed to be more important than pursuing higher education. Men went to several houses of their relatives to find a woman to marry. Nowadays, Cina Benteng descents can find their wife or husband from their work or education place.

However, recently there is a tendency that Cina Benteng descents prefer to marry other Chinese descents. In the Skype interview, Tanti noted that she does not mind making friends with people from other ethnic groups. Yet, she explained that none of her siblings is married to non-Chinese. Referring to Boski's (2008) acculturation attitudes, Tanti's decision to make friends with any ethnic groups reflects the notion of integration, in which the acculturating individuals feel the need of interaction with both groups. In contrary, when it comes to a desirable marriage, they went back to separation level, where they prefer people from the same ethnic group. There seems to be a desire or need to maintain their cultural identity or characteristics as Chinese descents. It is contradicting the history of Cina Benteng. Ethnic Cina Benteng was established by assimilation of Chinese migrants who married local Indonesians.

Tanti and her family have lived in several places. Until ten years old she lived in Kapling, one of the important areas for Cina Benteng community. Now they live in a costly housing area in Tangerang. They practice Buddhism. When talking about religion practices, she notices that some other Cina Benteng people now believe in other religions such as Catholic and Christianity. It should also be noted that she and her father went to a private Catholic school when they were a child. Here we can see another dimension of acculturating attitude. Students of private/Christian/Catholic schools are mostly Chinese descents, while of state schools are generally locals and Moslem Indonesians. Although assimilation has long been applied in Cina Benteng community, some modern Cina Benteng families unconsciously or subconsciously seem to encourage their children to spend time with other
Chinese. In this case, ethnicity might matter more.

Tanti's father, Hendri (53 yo), highlighted some differences of the past and the recent Cina Benteng traditions. In nowadays wedding, the bride and the groom wear western wedding dress. Wedding used to be held in the house of the couple; nowadays it is held in a wedding hall. During the interview, Hendri was able to tell each rituals of the wedding, while Tantifailed to name them. It is no longer about acculturation process of the local and acculturating group; global culture might intervene.

Furthermore, Hendri noted that early generations of Cina Benteng have invented "their own cultures". The third value or merging point has been established. It may show that the CinaBenteng have a desire to acquire two identities, that they belong to both Chinese and local (Indonesian) culture. Chinese language has long disappeared in Cina Benteng families. Instead, Cina Benteng created specific vocabulary which is close yet not similar to regular Indonesian language ('ambek' instead of 'marah' / upset, 'beberes' instead of 'beres-beres' / to tidy up, 'aleman' instead of 'manja' / spoiled, etc) (Kamus Bahasa Orang Cina Benteng, 2010). The food served in CinaBenteng families also reflects Boski's (2008) third value/merging point. Kecap Benteng SH (soy bean sauce $\mathrm{SH}$ ) is one of the main ingredients of Cina Benteng homemade dishes. SH is the initial of the founder, Siong Hin, a Cina Benteng descent.

Beside the language, myth also seems to fade away in the last generation of Cina Benteng. At some point in the interview, Tanti noted that her mother still reminds her not to cut her nails in the evening/night. It is believed to bring evil spirit. However, Tanti does not practice such beliefs anymore. In the end, when asked how she feels towards her ethnic group, Tanti comes to the idea of marginalisation. Being with people from other ethnic Chinese, she does not identify herself as one. She is completely aware that Cina Benteng is different from other ethnic Chinese. She finds no problems making friends with local Indonesians although being among other Indonesians would sometimes make her also feel 'different'. Home, as she explains, is where she meets other Cina Benteng people in Pasar Lama (a market dominated by Cina Benteng) or her childhood memory where she played with her Cina Benteng neighbour friends.

\section{Childhood memory as the foundation of ethnic identity}

For the second informant and his father, Cisadane

River and their childhood have greatly influenced their daily or social practices. Anjas, 22 yo, spends most of his spare time with friends from his childhood at the 'klenteng'. Although he would not mind having other friends (as he does in his school and workplace), he feels more comfortable surrounded by people he has spent time with since they were a kid. He and his father, Heri, were born and raised in Kapling, near Cisadane River. Heri recalled his childhood memory when he swam in the river with friends. It again makes Cina Benteng different from other Chinese groups. Due to the higher social status owned by other ethnic Chinese, the children might not be willing to play in places like a river. Heri also mentioned some traditions which are usually held at Cisadane River, such as boat races on day 15 th of the new year. Heri 
and Anjas still actively participate in such events every year. That contributes in shaping their identity as Cina Benteng. Heri interacts with people of any kinds. With his Indonesian (pribumi) friends he speaks Sundanese, one of the local dialects. Since he and his ancestors do not speak Chinese, Indonesian language is used when talking with other Chinese-Indonesians.

Heri owns a Chinese name, while Anjas does not. The latest generation of Cina Benteng does not have a Chinese name anymore. Like my father, his siblings and the earlier generations, Heri serves different function in different settings. At home he and family call each other in Chinese name, while with non-Chinese friends outside he is known as Heri. At home he is a Cina Benteng descent; outside he might fully mingle with Indonesians. Yet, those childhood memories at Cisadane River are strongly attached to his identity.

\section{CONCLUSION}

Ethnic Cina Benteng has encountered several levels of acculturation process. From losing the original language to create a new one, different generations respond to the acculturation in different ways. Although Chinese names are no longer relevant in their latest generation, identity as Chinese descents cannot easily be removed.

The fact that ethnic Cina Benteng might have assimilated with local Indonesians in the past and their low economic status also raise questions. If other Chinese groups are unwilling to assimilate, yet they have a better life (than ethnic Cina Benteng which has higher degree of assimilation) in the acculturating place, is assimilation still important? Into what extent should the acculturating individuals merge with the dominant group? If now some Cina Benteng descents prefer to marry other ethnic Chinese (not local Indonesians as their ancestors did), will it bring them back to the origins?

For Heri, my father and other Cina Benteng descents who were born and spent their childhood by the Cisadane River, the memory of swimming and practicing the traditions at the riverside might help keeping their identity as Cina Benteng.

\section{ACKNOWLEDGMENT}

The author acknowledges support from Lembaga Pengelola Dana Pendidikan (LPDP)/Indonesian Endowment Fund for Education, Ministry of Finance of Indonesia.

\section{REFERENCES}

Arif, M. (2014). Model kerukunan sosial pada masyarakat multikultural Cina Benteng (Kajian Historis dan Sosiologis). Sosio Didaktika, 1(1), 52-63. Retrieved from http://journal.uinjkt.ac.id/index. php/SOSIO-FITK/article/view/1212

Bennett, J. M., \& Bennett, M. J. (2004). Developing intercultural sensitivity: An ntegrative approach to global and domestic diversity. In D. Landis, J. M. Bennet, \& M. J. Bennet (Eds.), Handbook of Intercultural Training (3rd ed., pp. 147-165). California: Sage Publications.
Bennett, M. J. (1993). Towards ethnorelativism: A development model of intercultural sensitivity. In R. M. Paige (Ed.), Education for Intercultural Experience (2nd ed., pp. 21-71). Yarmouth: Intercultural Press.

Berry, J. W. (1990). Psychology of Acculturation: Understanding individuals moving between cultures. In R. W. Brislin (Ed.), Applied CrossCultural Psychology (pp. 232-253). Newbury Park: Sage Publications.

Boski, P. (2008). Five meanings of integration in acculturation research. International Journal of Intercultural Relations, 32(2), 142-153. http:/doi. org/10.1016/j.ijintrel.2008.01.005

Budiman, A. (2005). Portrait of the Chinese in PostSoeharto Indonesia. In T. Lindsey \& H. Pausacker (Eds.), Chinese Indonesians: Remembering, Distorting, Forgetting (pp. 95-104). Singapore: ISEAS Publications.

Coppel, C. A. (1999). The Indonesian chinese as foreign orientals in the Netherlands Indies. In T. Lindsey (Ed.), Indonesia: Law and Society (pp. 33-41). Sydney: The Federation Press.

Coppel, C. A. (2001). Chinese Indonesians in crisis: 1960s and 1990s perspectives on the Chinese Indonesians. In M. R. Godley \& G. J. Lloyd (Eds.), Perspectives on the Chinese Indonesians (pp. 2040). Adelaide: Crawford House.

Franciska, C. (2014, July 2). New voting power of Chinese Indonesians. BBC News. Retrieved from http:// www.bbc.com/news/world-asia-27991754

Kamus Bahasa Orang Cina Benteng. (2010). Retrieved from http://1214no.jigsy.com/entries/general/ kamus-bahasa-orang-cina-benteng

Lodico, M. G., Spaulding, D. T., \& Voegtle, K. H. (2006). Methods in Education Research: From theory to practice. New Jersey: John Wiley \& Sons.

Nurafni, T. (2012). History of China Benteng Indonesia. SD Production. Retrieved from https://www. youtube.com/watch?v=3264NWVRZjM

Qualitative Research. (n.d.). Retrieved from http://www. southalabama.edu/coe/bset/johnson/lectures/ lec12.htm

Sugianta, A., Lisa, M., \& Linda. (2012). Analisa Perubahan Sosial Masyarakat Sawan Lebak Wangi (Perbandingan Era Reformasi dan Orde Baru). Bina Nusantara. Retrieved from http:// eprints.binus.ac.id/23298/1/2011-2-00735-MD Abstrak001.pdf 